1 Berrino F, Capocaccia R, Esteve J. Survival of cancer patients in Europe: the EUROCARE study II. Lyons: International Agency for Research on Cancer, 1999.

2 National Cancer Institute. SEER Stat-cancer incidence public use database 1973-95. Bethesda, MD: NCI, 1998.

3 Richards MA, Westcombe AM, Lowe SB, Littlejohns P, Ramirez AJ. The influence of delay on survival in patients with breast cancer: a systematic review. Lancet 1999;353:1119-26.

4 Office for National Statistics. Cancer 1971-1997 [CD Rom]. London: Office of National Statistics, 1999

5 Secretary of State for Health. The new NHS. London: Stationary Office, 1997. (Cm380)

6 Staging announcements: FIGO Cancer Committee. Gynecol Oncol 1986:25:383-5.

7 Omura GA, Brady MF, Homesley HD, Yordan E, Major JF, Buchsbaum HJ. Long term follow-up and prognostic factors in advanced ovarian carcinoma; the Gynecologic Oncology Group experience. J Clin Oncol 1991;9:1138-50.

8 Flam F, Einhorn N, Sjovall K. Symptomatology of ovarian cancer. Eur J Obstet Gynecol Reprod Biol 1988;27:53-7.

9 Kjellgren O. Ovarian cancer-a symposium. Läkartindningen 1977;74 3333-5.
10 Wikborn C, Petterson F, Moberg PJ. Delay in diagnosis of epithelial ovarian cancer. Int J Obstet Gynecol 1996;52:263-7.

11 Lynn RB, Friedman LS. Irritable bowel syndrome. Med Clin North Am 1995;79:373-90.

12 Goff BA, Mandel L, Muntz HG, Melancon CH. Ovarian carcinoma diagnosis. Cancer 2000;89:2068-75.

13 Wikborn C, Petterson F, Silfversward C, Moberg PJ. Symptoms and diagnostic difficulties in ovarian epithelial cancer. Int J Obstet Gynecol 1993;42: 261-4.

14 Summerton N. Diagnosing cancer in primary care. Abingdon: Radcliffe 1999.

15 Leiderken BMJ, Hoogendam A, Buntinix F, Van der Weyden T, de Vet HC. Prolonged cough and lung cancer: the need for more general practise research to inform clinical decision making. Br J Gen Pract 1997 $47 \cdot 505$

16 Bell R, Petticrew M, Sheldon T. The performance of screening tests for ovarian cancer: results of a systematic review. Br J Obstet Gynecol 1998, 105:1136-47.

17 Jacobs IJ, Skates SJ, MacDonald N, Menon U, Rosenthal A, Prys Davies A Screening for ovarian cancer: a pilot randomised trial. Lance 1999;353:1207-10.

(Accepted 8 November 2001)

\title{
Depression and unintended pregnancy in the National Longitudinal Survey of Youth: a cohort study
}

\author{
David C Reardon, Jesse R Cougle
}

Psychological maladjustments after abortion are significantly associated with a history of depression. It has been suggested that prior psychological state is equally predictive of subsequent depression among women with unintended pregnancies regardless of whether they abort or carry to term. ${ }^{1}$ To examine this hypothesis we examined the National Longitudinal Study of Youth begun in 1979 with a nationwide cohort of 12686 American youths aged 14-21.

\section{Methods and results}

The outcome variable of interest, depression, was assessed in 1992 for a subset of 4463 women using the Center for Epidemiological Studies depression (CES-D) scale scored by professional interviewers. This 20 item scale has good test-retest reliability among diverse population subgroups. In 1992 women were also asked whether their first delivered pregnancy had been the result of an intended pregnancy. Women who responded "yes" or "didn't matter" were excluded from our sample.

To control for prior psychiatric state we used the four item version of the Rotter internal-external locus of control scale, which was administered in 1979 $(\mathrm{n}=6215$; mean 8.95, SD 2.1). The Rotter scale is intended to measure the extent to which people feel in control of their own destiny as opposed to having their fate decided by environment or chance. This abbreviated scale correlates well with self esteem, social class, and education. Higher external scores on the Rotter scale have been found to correlate with higher depression scores. ${ }^{2}$

Among all women surveyed depression scores were found to correlate with total family income in $1992(\mathrm{r}(3762)=-0.104, \mathrm{P}<0.0001)$, highest educational grade completed in $1992(\mathrm{r}(4459)=-0.202$, $\mathrm{P}<0.0001)$, age at first pregnancy event $(\mathrm{r}(3363)=$ $-0.164, \quad \mathrm{P}<0.0001)$, and 1979 Rotter scores $(\mathrm{r}(4423)=0.135, \mathrm{P}<0.0001)$. Depression scores were also significantly different between white (mean 9.48 , SD 9.5) and non-white people (mean 11.69, SD 10.0; $\mathrm{t}=7.47, \mathrm{P}<0.0001)$. These variables were used as controls.

The final sample used in these analyses includes only women for whom all control variables were available and who had their first abortion or first unintended delivery between 1980 and $1992(\mathrm{n}=421)$ On average, aborting women had had their first pregnancy in 1984 at age 22, and delivering women gave birth in 1986 at age 24. The mean Rotter score for aborting women and delivering women was 8.88 (SD $2.1)$ and 9.09 (2.2) respectively.

Women scoring in "high risk" range for clinical depression (CES-D score $>15$ ) who had their first abortion or first unintended childbirth between 1980 and 1992

\begin{tabular}{|c|c|c|c|c|c|c|c|c|}
\hline & \multicolumn{3}{|c|}{$\begin{array}{l}\text { Women with unintended births } \\
\text { (who did not abort) }\end{array}$} & \multicolumn{3}{|c|}{ Aborting women } & \multirow{2}{*}{$\begin{array}{l}\text { Adjusted } \\
\text { odds ratio* }\end{array}$} & \multirow[b]{2}{*}{$95 \% \mathrm{Cl}$} \\
\hline & Total & High risk & $\%$ High risk & Total & High risk & $\%$ High risk & & \\
\hline Married & 75 & 13 & 17.3 & 164 & 43 & 26.2 & 2.38 & 1.09 to 5.21 \\
\hline Unmarried & 53 & 16 & 30.2 & 129 & 37 & 28.7 & 0.94 & 0.43 to 2.03 \\
\hline All women & 128 & 29 & 22.7 & 293 & 80 & 27.3 & 1.54 & 0.91 to 2.61 \\
\hline
\end{tabular}

*Adjusting for family income, education, race, age at first pregnancy, and 1979 Rotter score.

Elliot Institute, PO Box 7348, Springfield, IL 62791-7348, USA David C Reardon director of research Jesse R Cougle researcher

Correspondence to: D C Reardon dcr@mine4ever.net

BMJ 2002;324:151-2 
The table shows the results of a logistic regression analyses, stratified by marital status in 1992. Among married women, those who aborted were significantly more likely to be at "high risk" of clinical depression compared with those who delivered unintended pregnancies. The difference was not significant among unmarried women.

\section{Comment}

Our results do not support the hypothesis that depression after unintended pregnancies is independent of outcome. Among married women those who previously carried an unintended first pregnancy to term were at less risk of subsequent depression than women who aborted. Rates of high risk depression scores were comparable among unmarried women, however. This may be due to the stress unmarried women may experience in raising a child without support or it may be related to this group's higher rate of concealing past abortions. Compared with national averages, unmarried women in the National Longitudinal Study of Youth report only 30\% of the expected abortions compared with married women, who report
$74 \%$ of the expected abortions. ${ }^{3}$ Since shame, secrecy, and thought suppression regarding an abortion are all associated with greater post-abortion depression, anxiety, and hostility, ${ }^{4}$ the high rate of concealing past abortions in the National Longitudinal Study of Youth sample, $60 \%$ overall, ${ }^{3}$ may significantly dilute the observed effect.

Contributors: DR and JC jointly conceived and designed the study and contributed to the analysis and interpretation. JC did the statistical calculations, and DR wrote the paper with substantive participation by JC.

Funding: Elliot Institute. The National Longitudinal Survey of Youth survey is conducted by the Center for Human Resource Research at Ohio State University and funded by the United States Department of Labor.

Conflicts of interest: None.

1 Major B, Cozzarelli C, Cooper ML, Zubek J, Richards C, Wilhite M, et al. Psychological responses of women after first-trimester abortion. Arch Gen Psychiatry. 2000;57:777-84.

2 Costello EJ. Locus of control and depression in students and psychiatric outpatients. J Clin Psychol 1982;38:340-3.

3 Jones EF, Forrest JD. Underreporting of abortion in surveys of U.S. women: 1976 to 1988. Demography 1992;29:113-26.

4 Major B, Gramzow RH. Abortion as stigma: cognitive and emotional implications of concealment. J Pers Soc Psychol. 1999;77:735-45.

(Accepted 29 August 2001)

\section{A memorable patient \\ Beware ill relatives who request second opinions}

Against my better judgment, I was persuaded by two of my wife's elderly spinster aunts to examine their sister, another spinster. "She's just not right," I was told by telephone. She arrived the following morning after a car journey of some 150 miles, and they had been correct-she was not right, she was in left heart failure. Subsequent examination in hospital also revealed that she had advanced syringomyelia and cancer of the breast, with widespread deposits. She died peacefully six days later. After passing on the sad news to the aunts, I was somewhat tartly told that she had willed her body to medical science, and would I kindly deal with it.

Ella, for that was her name, proved difficult to deal with. Getting the correct forms signed and witnessed by her next of kin involved two long car journeys to her home town, and then the local medical school with which she had registered her bequest informed me that they were no longer interested, since the body was outside their catchment area.

Fortunately, my own medical school was more accommodating. Sighs of relief were a little premature, however, because two weeks later my eldest daughter, a student physiotherapist at the same institution, calmly announced that she was soon going to start anatomical dissection. For once, I kept very quiet.

The months went by, and we forgot about Ella. Almost two years to the day, the telephone rang. The medical school had finished with Ella and said that, yes, it was usual to cremate. In the meantime, both of the other sisters had died, and so, on a lovely spring morning, only my wife, my student daughter, and I gathered to pay our last respects. A youthful vicar arrived, obviously unbriefed, and immediately sought to console us on our recent bereavement, whereupon my irreverent daughter remarked that on the contrary, we were happy that it was all nearly over. I had to take the vicar to one side to explain the circumstances; he, in turn, confided that this was his first cremation.
At first, all went well; the four of us sat in a cosy circle, accompanied by the inhouse organist, who had a nasty cough that merited investigation. All went well, that is, until we reached the point when Ella's body and soul were commended to God (for the first of many times during the service). My daughter started to giggle, rightly pointing out that, presumably, Ella's soul had made the journey two years earlier. After a moment of quiet reflection, the young vicar agreed, and, from then on, he manfully tried to ad lib his way through the rest of the service, sending only the body on that day, since the soul had probably arrived two years previously. Nevertheless, despite his best intentions, on at least two occasions, the vicar sent the soul without the body and, on another occasion, neglected to send either. The cremation service was not designed for those who leave their bodies to medical science, and Ella would have loved it-she always had a great sense of humour.

The end of the service came none to soon for the young man, and he left us with a dazed look in his eyes. Funnily enough, I recognised that look, for I had often seen it over the years on the faces of preregistration house officers at the end of their first day's work on the wards.

\section{David Fisher former general physician, Cardiff}

We welcome articles up to 600 words on topics such as A memorable patient, A paper that changed my practice, $M y$ most unfortunate mistake, or any other piece conveying instruction, pathos, or humour. If possible the article should be supplied on a disk. Permission is needed from the patient or a relative if an identifiable patient is referred to. We also welcome contributions for "Endpieces," consisting of quotations of up to 80 words (but most are considerably shorter) from any source, ancient or modern, which have appealed to the reader. 